\title{
肝不全用経腸栄養剤（SF-1008C）の肝性脳症 改善効果に関する研究
}

一アンモニア負荷門脈下大静脈吻合ラットにおける血浆中及び 脳内遊離アミノ酸濃度, 脳内アミン濃度と脳波に対する作用一

木戸 康博, 杉山 光太, 中尾 誠仁
樫山 英二, 須田 武雄, 宮本剛八郎
清水 剛文, 新谷 成之, 郡 英明
大塚製薬 (株) 徳島研究所*
(昭和61年 4 月10日 [特])

要約 : branched-chain amino acid (BCAA)を多く, aromatic amino acid (AAA) を少なく配合し た肝不全用経腸栄盖剂 SF-1008C の肝性脳症改善効果を検討した。肝性脳症による昏睡状態のモデルと して門脈下大静脈吻合ラットに $10 \%$ ammonium acetate ( $3 \mathrm{ml} / \mathrm{kg}$, i.p.) を投与し (PCS 群), 血中 ammonia 濃度, 血漿中和よび脳内遊離 amino acid 濃度, 脳内 amine 濃度, 脳波を測定した. PCS 群では, 擬手術群 (Sham群) に比べて血中 ammonia 濃度, 血漿中遊離 AAA 濃度が有意に増加 した. その結果, 血漿中 BCAA/AAA 比は著しく低下した. 血墏中遊離 amino acid 濃度異常に伴い脳 内遊離 AAA 濃度が Sham 群に比べ PCS 群で有意に増加した. さらに, 脳内 amine 濃度において, PCS 群は, Sham 群にくらべ tryptophan (Trp) 及び 5-hydroxyindole acetic acid (5-HIAA) 濃度 が有意に増加し, dopamine（DA）濃度が有意に減少した。 しかし, serotonin (5-HT) 及び norepinephrine (NE) 濃度に変化は認められなかった. 脳波では Sham 群に比べ PCS 群で脳波電位の低下が 認められた. SF-1008C は, 增加した血墏中遊離 AAA, 脳内遊離 AAA, 脳内 Trp, 脳内 5-HIAA 濃度 を減少させ，脳波電位の低下を抑制した。一方，良質蛋白質である卵蛋白質の amino acid 組成を基とし た成分栄養剂 ED-AC は, 血漿中遊離 AAA, 脳内遊離 AAA, 脳内 Trp, 脳内 5-HIAA 濃度の減少を 認めず, 脳波電位の低下も抑制しなかった。これらの結果は SF-1008C が血漿中遊離 amino acid 濃度 を是正することにより脳内遊離 amino acid 濃度, ひいては脳内 amine 代謝, 脳波に影響を及ぼしてい ることを示唆する. さらに, 血漿中 BCAA/AAA 比と脳内 BCAA/AAA 比との間には, 正の相関関係 $(\mathrm{r}=0.9585)$ が認められ，血漿中遊離 amino acid 濃度が脳内遊離 amino acid 濃度を反映しているこ とが示唆された.

緒 言

肝性昏睡は，肝不全時に生じる代謝障害あるいは門脈 大循環副血行路形成により引き起こされる特有な精神神 経症状である1)。このような重症肝疾患患者に和いて は, 血漿中遊離了ミノ酸濃度の不均衡が報告されてい る.つまり, tyrosine (Tyr), phenylalanine (Phe) などの aromatic amino acid (AAA) 濃度が増加し, valine (Val), isoleucine (Ile), leucine (Leu)など の branched-chain amino acid (BCAA) 濃度が減少 しているため BCAA と AAA のモル比 (BCAA/AAA

* 函771-01 徳島市川内町加賀須野463-10

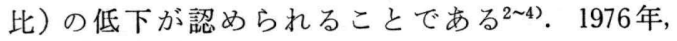

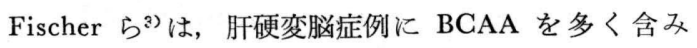
$\mathrm{AAA}$ の少ない特殊組成アミノ酸混合液を静脈内に投与 することにより肝性昏睡から覚醒することを報告した. また, 経口的に BCAA を投与する経腸栄養を行って も, 同様の脳症改善作用が 観察され $れ^{5,6)}$, 重症肝疾患例 の栄養管理と維持にも BCAA が有用であることがわか ってきた. 本試験では, 肝性脳症による昏睡状態のモ デル動物として, 門脈下大静脈吻合 (PCS) ラットに ammonia を負荷し, 血中 ammonia 濃度, 血漿中打 よび脳内遊離 amino acid 濃度, 脳内 amine 濃度,

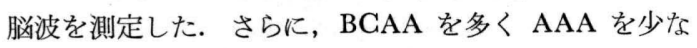
く配合した肝不全用経腸栄養剂 SF-1008C の効果につ 
いて良質蛋白質である卵蛋白質のアミノ酸組成を基とし た成分栄盖剈（ED-AC，味の素）と比較検討したので 報告する.

\section{実 験 材 料}

\section{1. 実験動物}

実験には, 体重 $180 \sim 200 \mathrm{~g}$ (7 週齢) の SpragueDawley 系雄性ラット（日本チャールス・リバー）を使 用した.ラットは予備飼育および実験期間を通じて, 室 温 $23 \pm 2^{\circ} \mathrm{C}$, 湿度 $60 \pm 10 \%$ の動物飼育室で飼育した.

\section{2. 被験薬剂}

被験薬剂 SF-1008C の組成を表1飞示した. SF1008C の投与量は, 急性肺炎回復期, 慢性肝炎, 肝硬 変の食事中の蛋白質摂取量が $80 \mathrm{~g} /$ day であることか ら², この 1 日量の二分の一の量を SF-1008C で摂取す る場合を $2.5 \mathrm{~g} / \mathrm{kg}$ ，すべてを SF-1008C で撕取する場 合を $5.0 \mathrm{~g} / \mathrm{kg}$ とし，本試験に用いた。 また，対照薬は 成分栄養剤 ED-AC (エレンタール, 味の素) を使用し た (表 1$)^{8}$.

\section{実 験 方 法}

1. 肝性脳症モデル（ammonia 負荷 PCS ラット）の 作成

小畠ら99のボタン改良法による簡便術式に準じ PCS 手術を抗こなった。つまり,ラットを一夜絶食した後, ether 麻酔下に開腹しポリェチレン製のボタンを用い門 脈と下大静脈を吻合した。手術時間は門脈血流遮断が 6 分以内, 下大静脈血流遮断が 2 分以内とした. また, 比 較対照群として開腹し血流遮断のみを行った擬手術ラッ トを作成した (Sham 群) ${ }^{10)}$ 。この PCS ラットに10\% ammonium acetate 溶液 $3 \mathrm{ml} / \mathrm{kg}$ を腹腔内投与して 肝性脳症モデルとして実験に供した.

\section{2. 血漿中および脳内遊離 amino acid 濃度に対する} 作用

PCS 手術 2 週間後, 一夜絶食して実験に用いた。薬 剤の投与量は SF-1003C $2.5 \mathrm{~g} / 10 \mathrm{ml} / \mathrm{kg}$ (SF 2.5 群), $5.0 \mathrm{~g} / 10 \mathrm{ml} / \mathrm{kg}$ (SF 5.0 群) あるいは ED-AC $5.0 \mathrm{~g} / 10$ $\mathrm{ml} / \mathrm{kg}$ (ED5.0 群) であり, 対照群である Sham 群およ

Table 1 Nutrient and amino acid composition of SF-1008C and ED-AC

\begin{tabular}{|c|c|c|c|}
\hline & & SF-1008C & $\mathrm{ED}-\mathrm{AC}^{8)}$ \\
\hline Energy & $(\mathrm{kcal} / 100 \mathrm{~g})$ & 419 & 375 \\
\hline \multicolumn{4}{|c|}{$(\mathrm{g} / 100 \mathrm{~g})$} \\
\hline Cas & & 1.0 & - \\
\hline Pep & & 13.0 & - \\
\hline Ami & & 13.0 & 17.6 \\
\hline \multicolumn{4}{|c|}{ Carbohydrate } \\
\hline Dex & & 62.1 & 79.4 \\
\hline Lipid & $(\mathrm{g} / 100 \mathrm{~g})$ & & 0.7 \\
\hline \multicolumn{2}{|c|}{ Rice oil } & 7.0 & - \\
\hline \multicolumn{2}{|l|}{ Others } & 3. $9^{*}$ & $2.3^{*}$ \\
\hline \multicolumn{4}{|c|}{ Amino acid composition (g/100 g Protein) } \\
\hline \multicolumn{2}{|c|}{ Valine } & $12.5^{* *}$ & 5.33 \\
\hline \multicolumn{2}{|c|}{ Leucine } & 15. $8^{* *}$ & 6.84 \\
\hline \multicolumn{2}{|c|}{ Isoleucine } & $14.3^{* *}$ & 4.89 \\
\hline \multicolumn{2}{|c|}{ Phenylalanine } & $1.2 * *$ & 6.63 \\
\hline \multicolumn{2}{|c|}{ Tyrosine } & $0.3^{* *}$ & 0.84 \\
\hline \multicolumn{2}{|c|}{ Tryptophan } & $0.5^{* *}$ & 1.15 \\
\hline \multicolumn{2}{|c|}{ Methionine } & $0.4^{* *}$ & 4.93 \\
\hline \multicolumn{2}{|c|}{ Threonine } & 2. $0 * *$ & 3.98 \\
\hline \multicolumn{2}{|c|}{ Lysine } & $4.2^{* *}$ & 5.41 \\
\hline \multicolumn{2}{|c|}{ Others } & 48. $8^{* *}$ & 60.00 \\
\hline
\end{tabular}

* Vitamins and electrolytes are contained in proper quantities. ** Analytical value. 
び PGS 群には蒸留水 $10 \mathrm{ml} / \mathrm{kg}$ をそれぞれ経口投与し た. 各薬剤投与 90 分後に $10 \%$ ammonium acetate 溶 液を $3 \mathrm{ml} / \mathrm{kg}$ 用量で腹腔内投与した. 正確に 30 分後 ether 麻醉下に下大静脈から採血し, 血中 ammonia 濃度抢よび血漿中遊離 amino acid 濃度分析用試料を 得た。また, 採血後速やかに脳および肝臓の摘出, 秤量 を行い, 脳は液体窒素によって凍結し脳内遊離 amino acid 濃度分析用試料とした。 血中 ammonia 濃度 は, 藤井・奥田変法 (Ammonia-Test Wako, 和光純 薬)によって測定した ${ }^{11)}$. 血墏中和よび脳内遊離 amino acid 濃度の分析は, 既報 ${ }^{10\rangle}$ の方法に従い, 日立高速了

ミノ酸分析計 (835-50型)によって測定した.

\section{3. 脳内 amine 濃度に対する作用}

アンモニア負荷 PCS ラット作成および薬剤投与は, 前述 2. と同様に行った. 各薬剤投与 90 分後に $10 \%$ ammonium acetate 溶液を $3 \mathrm{ml} / \mathrm{kg}$ 用量で腹腔内投 与した. 正確に 30 分後, 既報 ${ }^{100}$ に準じマイクロウェー ブ照射後直ちに脳を摘出し, $5 \mathrm{mM} \mathrm{Na} 2 \mathrm{~S}_{2} \mathrm{O}_{5}$ を含む $50 \mathrm{mM} \mathrm{HClO}_{4}$ 溶液を加え $20 \%$ ホモジネートに調製 し, 脳内 tryptophan (Trp), serotonin (5-HT), 5-hydroxyindole acetic acid (5-HIAA), dopamine (DA), norepinephrine (NE) を抽出, 定量した.

\section{4. 脳波に対する作用}

PCS 手術 1 週間後, ether 麻酔下に皮質脳波用慢性 ネジ電極を後頭部に植え込み頭部ソケットに接続して歯 科用セメントで固定した. さらに 1 週間後, 脳波を測定 した. 脳波の測定は, 防音防電室内の透明アクリル樹脂 製ケージに入れて, 脳波計（日本光電：EEG-4112）に て連続記録し、モニターテレビで行動を観察した. 薬剤 の投与量は, SF-1008C $5.0 \mathrm{~g} / 10 \mathrm{ml} / \mathrm{kg}$ (SF5.0 群), ED-AC $5.0 \mathrm{~g} / 10 \mathrm{ml} / \mathrm{kg}$ (ED5.0 群) であり, 対照群で ある Sham 群, および PCS 群には蒸留水 $10 \mathrm{ml} / \mathrm{kg}$ をそれぞれ経口投与した．各薬剤投与 90 分後に，10\% ammonium acetate 溶液 $3 \mathrm{ml} / \mathrm{kg}$ を腹腔内に投与し た. 脳波の記録は，被験薬剂投与前 30 分から，10\% ammonium acetate 溶液 $3 \mathrm{ml} / \mathrm{kg}$ 腹腔内投与後 50 分 目まで行った.

脳波パワースペクトルは, 被験薬剤投与前に 10 秒間の パワースペクトルを 5 分間隔で 7 回 (三栄測器: シグナ ルプロセッサー7TO7), 10\% ammonium acetate 溶 液腹腔内投与後に 10 分間のパワースペクトルを 5 分間隔 で13回求めた.

\section{5. 統計学的処理}

結果は平均値と標準偏差で表した。また，Student’s $t$-test によって有意差検定をし， $\mathrm{P}<0.05$ の場合を有意 と判定した.

\section{実 験 結 果}

\section{1. 血漿中および脳内遊離 amino acid 濃度に対する} 作用

1）体重, 肝臟重量および脳重量

体重, 肝臓重量および脳重量に関する結果を表 2 に示 した. 体重は, Sham 群に比べ PCS 群で有意に低值 を示した. 肝臓重量は Sham 群に比べ PCS 群, SF2.5 群, SF5.0 群, ED5.0 群で有意に減少し, 薬剤を投与 することによる変化は認められなかった. 脳重量は, 各 群間において有意な差は認められなかった。

2）血中 ammonia 濃度

血中 ammonia 濃度に関する結果を図1に示した. PGS 群の血中 ammonia 濃度は, Sham 群に比べ有 意に $(\mathrm{P}<0.01)$ 増加した. SF2.5 群, SF5.0 群では PCS 群の血中 ammonia 濃度より低值を示したが, ED5.0 群では高値を示した. ED5.0 群に比べ SF2.5 群, SF5.0 群の血中 ammonia 濃度は, 有意飞減少し た.

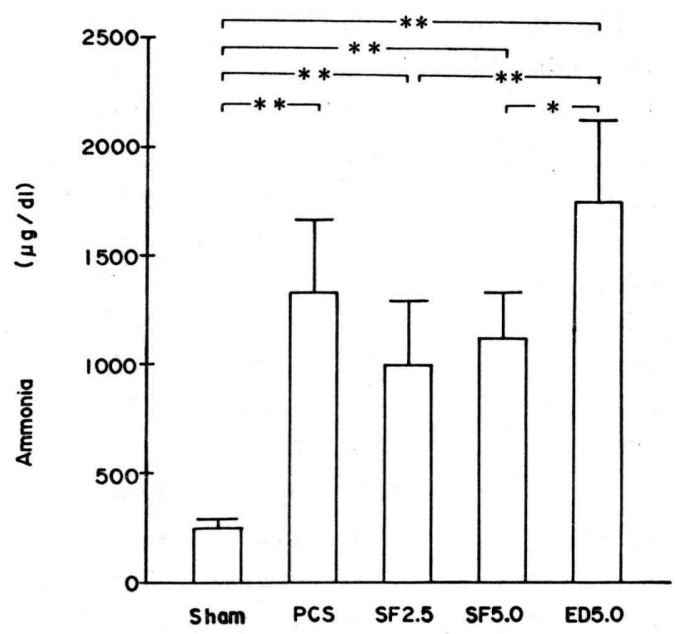

Fig. 1 Effect of SF-1008C on blood ammonia concentration after acute ammonia loading in portacaval shunted rats. The results are expressed as mean \pm standard deviation. Statistical significance is determined by Student's $t$-test. $* \mathrm{P}<0.05$, ** $\mathrm{P}<0.01$.

3）血漿中遊離 amino acid 濃度

血漿中遊離 amino acid 濃度に関する結果を表 3 に 
Table 2 Effect of SF-1008C on body, liver, and brain weight after acute ammonia loading in portacaval shunted rats

\begin{tabular}{ccccccc}
\hline \multicolumn{1}{c}{ Group } & & Sham (6) & PCS (5) & SF2.5 (5) & SF5.0 (5) & ED5.0 (5) \\
\hline Body weight & $(\mathrm{g})$ & $272.3 \pm 16.4 \# \#$ & $229.2 \pm 19.0 * *$ & $246.8 \pm 23.0$ & $255.2 \pm 17.8$ & $249.8 \pm 21.5$ \\
Liver weight & $(\mathrm{g})$ & $7.92 \pm 0.50 \# \#$ & $4.99 \pm 0.87 * *$ & $5.74 \pm 1.50^{*}$ & $6.27 \pm 0.92^{* *}$ & $5.72 \pm 0.76^{* *}$ \\
\% Liver weight & $2.91 \pm 0.09 \# \#$ & $2.17 \pm 0.24 * *$ & $2.30 \pm 0.37 *$ & $2.46 \pm 0.29 *$ & $2.28 \pm 0.13 * *$ \\
Brain weight & $(\mathrm{g})$ & $1.87 \pm 0.06$ & $1.91 \pm 0.04$ & $1.88 \pm 0.04$ & $1.88 \pm 0.04$ & $1.90 \pm 0.02$ \\
\hline
\end{tabular}

Results are given as mean \pm standard deviation with the numbers of animals shown in parentheses. Results significantly different from Sham and PCS are indicated by: $* \mathbf{P}<0.05, * * \mathbf{P}<0.01$ and $\# \mathrm{P}<0.05$, \#\# $\mathrm{P}<0.01$, respectively.

Table 3 Effect of SF-1008C on plasma free amino acids concentration after acute ammonia loading in portacaval shunted rats

\begin{tabular}{|c|c|c|c|c|c|}
\hline Group & Sham (6) & PCS (5) & SF2. 5 (5) & SF5. 0 (5) & ED5. 0 (5) \\
\hline Val & $187 \pm 19$ & $198 \pm 37$ & $190 \pm 51$ & $292 \pm 102$ & $124 \pm 13^{* * \# \# ~}$ \\
\hline Ile & $91 \pm 10$ & $94 \pm 14$ & $82 \pm 27$ & $113 \pm 52$ & $58 \pm 9 * * \# \#$ \\
\hline Leu & $139 \pm 17$ & $155 \pm 26$ & $121 \pm 43$ & $162 \pm 72$ & $92 \pm 11^{* * \# \# ~}$ \\
\hline Tyr & $109 \pm 12 \# \#$ & $155 \pm 24 * *$ & $96 \pm 18 \# \#$ & $77 \pm 3^{* * \# \# ~}$ & $127 \pm 7 *$ \\
\hline Phe & $86 \pm 8 \# \#$ & $119 \pm 15^{* *}$ & $87 \pm 15 \# \#$ & $74 \pm 7 * \# \#$ & $143 \pm 15^{* * \#}$ \\
\hline Cys & $70 \pm 8 \# \#$ & $34 \pm 8^{* *}$ & $36 \pm 9 * *$ & $36 \pm 10^{* *}$ & $44 \pm 9 * *$ \\
\hline Met & $61 \pm 6$ & $70 \pm 8$ & $46 \pm 5^{* * \# \#}$ & $35 \pm 3^{* * \# \# ~}$ & $102 \pm 15^{* * \# \#}$ \\
\hline $\operatorname{Trp}$ & $83 \pm 9$ & $87 \pm 8$ & $78 \pm 8$ & $80 \pm 8$ & $92 \pm 11$ \\
\hline Thr + Gln & $1077 \pm 95$ & $1043 \pm 56$ & $825 \pm 87 * * \# \#$ & $807 \pm 93^{* * \# \# ~}$ & $799 \pm 87 * * \# \#$ \\
\hline Lys & $428 \pm 72$ & $471 \pm 99$ & $347 \pm 51 \#$ & $324 \pm 70 * \#$ & $397 \pm 46$ \\
\hline $\mathrm{Ala}$ & $224 \pm 41 \# \#$ & $453 \pm 92 * *$ & $573 \pm 125 * *$ & $709 \pm 63^{* * \# \# ~}$ & $628 \pm 73^{* * \#}$ \\
\hline Arg & $149 \pm 13 \# \#$ & $201 \pm 20 * *$ & $178 \pm 26^{*}$ & $179 \pm 17^{* *}$ & $181 \pm 24^{*}$ \\
\hline Asp & $6 \pm 0$ & $6 \pm 0$ & $6 \pm 2$ & $6 \pm 0$ & $7 \pm \quad 3$ \\
\hline Glu & $73 \pm 14$ & $68 \pm 25$ & $57 \pm 20$ & $56 \pm \quad 7 *$ & $55 \pm 15$ \\
\hline Gly & $289 \pm 31$ & $303 \pm 22$ & $387 \pm 65^{* * \#}$ & $496 \pm 65^{* * \# \# ~}$ & $268 \pm 33$ \\
\hline $\mathrm{His}$ & $68 \pm 7 \# \#$ & $97 \pm 13^{* *}$ & $77 \pm 14$ & $74 \pm 8 \#$ & $92 \pm \quad 7 * *$ \\
\hline Pro & $105 \pm 14 \# \#$ & $137 \pm 12^{* *}$ & $188 \pm 24 * * \# \#$ & $243 \pm 27 * * \# \#$ & $153 \pm 27 * *$ \\
\hline Ser & $232 \pm 30$ & $231 \pm 23$ & $216 \pm 31$ & $227 \pm 17$ & $252 \pm 18$ \\
\hline TAA & $3472 \pm 326$ & $3916 \pm 413$ & $3587 \pm 500$ & $3982 \pm 317^{*}$ & $3610 \pm 233$ \\
\hline BCAA & $416 \pm 45$ & $447 \pm 75$ & $393 \pm 121$ & $566 \pm 225$ & $275 \pm 32 * * \# \#$ \\
\hline AAA & $194 \pm 18 \# \#$ & $284 \pm 35^{* * *}$ & $183 \pm 32 \# \#$ & $151 \pm 9 * * \# \#$ & $270 \pm 14 * *$ \\
\hline BCAA/AAA & 2. $14 \pm 0.13 \# \#$ & $1.64 \pm 0.21^{* *}$ & $2.16 \pm 0.51$ & $3.77 \pm 1.56 \#$ & $1.02 \pm 0.14^{* * \# \# ~}$ \\
\hline
\end{tabular}

Results are expressed as nanomoles per milliliter and are given as mean \pm standard deviation with the numbers of animals shown in parentheses. Results significantly different from Sham and PCS are indicated by: * $\mathrm{P}<0.05$, ** $\mathrm{P}<0.01$ and $\# \mathrm{P}<0.05$, \#\# $\mathrm{P}<0.01$, respectively.

示した. Sham 群に対し PCS 群において分枝鎖アミ ノ酸である Val, Ile, Leu 濃度は変化しなかったが, 芳香族アミノ酸である Tyr, Phe 濃度は有意に増加し た. PCS 手術後 ammonium acetateを負荷した動
物に SF-1008C を $2.5 \mathrm{~g} / \mathrm{kg}$ (SF2.5 群) 及び $5.0 \mathrm{~g} / \mathrm{kg}$ (SF5.0 群) 投与することにより Tyr, Phe, Met, Thr +Gln および Lys 濃度が用量に依存して減少した。一 方, PGS 群に比較して ED5.0 群では, Val Ile, Leu, 
$\mathrm{Thr}+\mathrm{Gln}$ 濃度が減少し, Phe おょよ゙ Met 濃度が有意 に増加した. PCS 群は Sham 群に対し BCAA 濃度は 同程度であったが, $\mathrm{AAA}$ 濃度が増加したため BCAA/ AAA 比は有意に低下した. SF-1008C 投与群では, BCAA 濃度に有意な変化が認められなかったが, AAA 濃度が SF-1008C の投与量に依存して, Sham 群と 同等もしくはそれ以上に上昇した. 一方, ED5.0 群で は, AAA 濃度は PCS 群とほぼ同じ高い值を示し, BCAA 濃度が大きく減少したため, BCAA/AAA 比は 5 群中, 最も低くなった.

4) 脳内遊離 amino acid 濃度

脳内遊離 amino acid 濃度に関する結果を表4 亿示 した. 脳内 Trp 濃度は 5-HT 関連として amineの 項で結果を示した. PCS 群はSham 群に比べ総遊離 amino acid 濃度, BCAA 濃度, および AAA 濃度が 有意に増加した。しかし，BGAA/AAA 比は殆ど変化し
なかった。

SF-1008C 投与群では, PCS 群に比べ BCAA 濃度 に有意な変化がみられなかったものの, AAA 濃度は SF-1008C の投与量に依存して減少したため，BCAA/ AAA 比は投与量に依存して上昇した. 一方, ED5.0 群 では, 総遊離 amino acid 濃度は PCS 群とほぼ同じ 値を示し, AAA 濃度についても最も減少したため, BCAA/AAA 比は血漿中と同様 5 群中に捻いて, 最低 値を示した.

全群の血嶈中と脳内のそれぞれの BCAA/AAA 比と の間には, 正の相関関係が得られた（図 2 ).

\section{2. 脳内 amine 濃度に対する作用}

脳内 amine 濃度に関する結果を表 5 亿示した. PCS 群は Trp 33.94, 5-HT 2.52, 5-HIAA 2.67, DA 6.72, NE $2.27 \mathrm{nmol} / \mathrm{g}$ tissue であり, Sham 群の Trp 17.12, 5-HT 2.48, 5-HIAA 1.64 , DA 7.69 , NE $2.48 \mathrm{nmol} / \mathrm{g}$

Table 4 Effect of SF-1008C on brain free amino acids concentration after acute ammonia loading in portacaval shunted rats

\begin{tabular}{|c|c|c|c|c|c|}
\hline Group & Sham (6) & PGS (5) & SF2. 5 (5) & SF5. 0 (5) & ED5. 0 (5) \\
\hline Val & $135 \pm 8 \#$ & $172 \pm 24^{*}$ & $161 \pm 20^{*}$ & $197 \pm 17 * *$ & $127 \pm 16 \# \#$ \\
\hline Ile & $69 \pm 3 \#$ & $92 \pm 13^{*}$ & $74 \pm 12$ & $90 \pm 19$ & $66 \pm 8 \# \#$ \\
\hline Leu & $133 \pm 6 \# \#$ & $181 \pm 23 * *$ & $135 \pm 24 \#$ & $149 \pm 27$ & $129 \pm 19 \# \#$ \\
\hline Tyr & $161 \pm 4 \# \#$ & $251 \pm 38 * *$ & $170 \pm 25 \# \#$ & $133 \pm 9 * * \# \#$ & $244 \pm 38^{* *}$ \\
\hline Phe & $157 \pm 10 \# \#$ & $211 \pm 15^{* *}$ & $166 \pm 18 \# \#$ & $135 \pm 15^{* \# \#}$ & $269 \pm 55^{* *}$ \\
\hline Cys & $33 \pm 2 \# \#$ & $28 \pm 1 * *$ & $28 \pm 1^{* *}$ & $29 \pm 0$ & $28 \pm 2^{* *}$ \\
\hline Met & $83 \pm 4 \# \#$ & $95 \pm 5^{* *}$ & $61 \pm 5^{* * \# \#}$ & $47 \pm 5^{* * \# \#}$ & $140 \pm 32 * \#$ \\
\hline $\operatorname{Trp}$ & - & - & - & - & - \\
\hline Thr + Gln & $7862 \pm 381 \# \#$ & $11782 \pm 1784^{* *}$ & $10897 \pm 1376^{* *}$ & $10463 \pm 303 * *$ & $12414 \pm 1842^{* *}$ \\
\hline Lys & $452 \pm 48$ & $441 \pm 81$ & $407 \pm 39$ & $352 \pm 61^{*}$ & $416 \pm 78$ \\
\hline Ala & $790 \pm 71 \# \#$ & $1477 \pm 309^{* *}$ & $1229 \pm 222 * *$ & $1375 \pm 156^{* *}$ & $1694 \pm 360^{* *}$ \\
\hline Arg & $412 \pm 17 \# \#$ & $365 \pm 16^{* *}$ & $317 \pm 12^{* * \# \#}$ & $304 \pm 28 * * \# \#$ & $262 \pm 47^{* * \# \#}$ \\
\hline Asp & $2250 \pm 87 \# \#$ & $1650 \pm 158^{* *}$ & $1565 \pm 51^{* *}$ & $1525 \pm 76^{* *}$ & $1573 \pm 292^{* *}$ \\
\hline Glu & $9577 \pm 330 \# \#$ & $8923 \pm 194 * *$ & $8209 \pm 283^{* * \# \# ~}$ & $8433 \pm 388^{* * \#}$ & $8375 \pm 988$ \\
\hline Gly & $1425 \pm 63$ & $1484 \pm 63$ & $1372 \pm 105$ & $1315 \pm 64 * \# \#$ & $1360 \pm 198$ \\
\hline $\mathrm{His}$ & $95 \pm 7 \#$ & $137 \pm 22 *$ & $107 \pm 16 \#$ & $85 \pm 10 \# \#$ & $163 \pm 41^{*}$ \\
\hline Pro & $98 \pm 8 \# \#$ & $139 \pm 19 * *$ & $129 \pm 12^{* *}$ & $128 \pm 10^{* *}$ & $149 \pm 31^{*}$ \\
\hline Ser & $968 \pm 60$ & $946 \pm 50$ & $794 \pm 18^{* * \# \#}$ & $839 \pm 52 * * \#$ & $907 \pm 133$ \\
\hline TAA & $24699 \pm 599 \#$ & $28373 \pm 2313 *$ & $25822 \pm 1617$ & $25599 \pm 526^{*}$ & $28315 \pm 3993$ \\
\hline BCAA & $337 \pm 16 \#$ & $445 \pm 60^{*}$ & $371 \pm 54$ & $436 \pm 61^{*}$ & $321 \pm 42 \# \#$ \\
\hline AAA & $318 \pm 13 \# \#$ & $462 \pm 51^{* *}$ & $336 \pm 42 \# \#$ & $268 \pm 24 * * \# \#$ & $513 \pm 92^{* *}$ \\
\hline BCAA/AAA & $1.06 \pm 0.02$ & $0.97 \pm 0.11$ & $1.11 \pm 0.19$ & $1.65 \pm 0.34 * \# \#$ & $0.63 \pm 0.04 * * \# \#$ \\
\hline
\end{tabular}

Results are expressed as nanomoles per gram wet tissue and are given as mean \pm standard deviation with the numbers of animals shown in parentheses. Results significantly different from Sham and PGS are indicated by: * $\mathrm{P}<0.05$, ** $\mathrm{P}<0.01$ and $\# \mathrm{P}<0.05$, \#\# $\mathrm{P}<0.01$, respectively. 


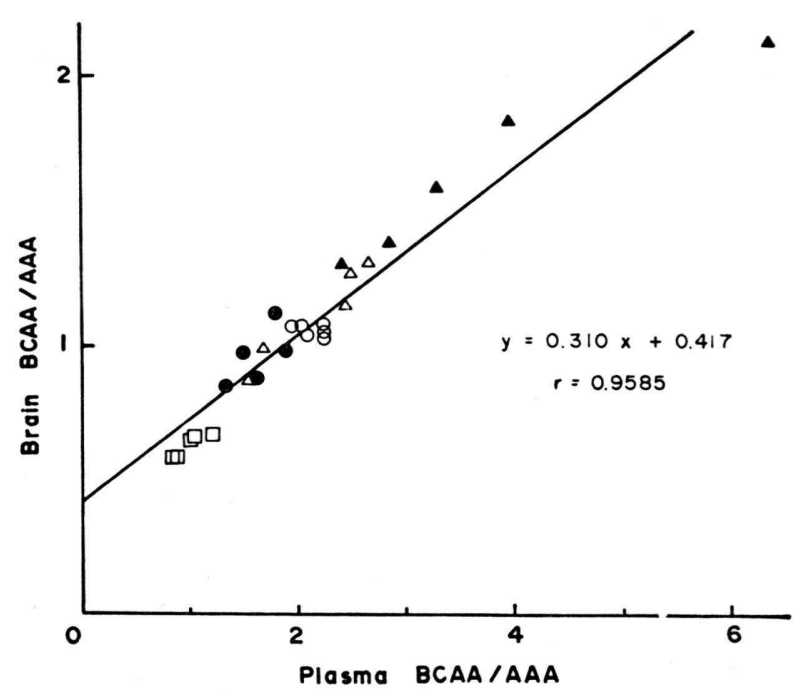

Fig. 2 Relationship of brain BCAA/AAA ratio to plasma BCAA/AAA ratio. Line represents linear regression of brain BCAA/AAA ratio against plasma BCAA/AAA ratio using values from Sham (O), PCS ( $)$, SF2.5 ( $\triangle$ ), SF5.0 (A) and ED5.0 ( $\square$ ).

Table 5 Effects of SF-1008C on intracerebral amine concentration in portacaval shunted rats with ammonia loading

\begin{tabular}{lccccc}
\hline Group & Sham (5) & PCS (5) & SF2.5 (5) & SF5.0 (5) & ED5.0 (4) \\
\hline Trp & $17.12 \pm 1.47 \#$ & $33.94 \pm 9.35^{*}$ & $24.83 \pm 5.24^{*}$ & $18.53 \pm 4.36 \#$ & $29.75 \pm 1.22^{* *}$ \\
5-HT & $2.48 \pm 0.19$ & $2.52 \pm 0.43$ & $2.20 \pm 0.59$ & $2.08 \pm 0.39$ & $2.44 \pm 0.22$ \\
5-HIAA & $1.64 \pm 0.09 \#$ & $2.67 \pm 0.43^{*}$ & $2.02 \pm 0.45$ & $1.85 \pm 0.34 \#$ & $2.21 \pm 0.23^{* *}$ \\
DA & $7.69 \pm 0.51 \#$ & $6.72 \pm 0.63^{*}$ & $6.68 \pm 0.89$ & $7.09 \pm 0.49$ & $7.10 \pm 0.29$ \\
NE & $2.48 \pm 0.24$ & $2.27 \pm 0.19$ & $2.10 \pm 0.15^{*}$ & $2.19 \pm 0.15^{*}$ & $2.19 \pm 0.18$ \\
\hline
\end{tabular}

Results are expressed as nanomoles per gram wet tissue and are given as mean \pm standard deviation with the numbers of animals shown in parentheses. Results significantly different from Sham and PGS are indicated by: $* \mathrm{P}<0.05$, ** $\mathrm{P}<0.01$ and $\# \mathrm{P}<0.05$, respectively.

tissue と比較すると, Trp 特よび 5-HIAA 濃度は有 意に増加し，DA 濃度は有意に減少した。 5-HT および NE 濃度は Sham 群と PCS 群との間に有意な差は認 められなかった.

5-HT 代謝系のらち, Trp 濃度は, SF2.5 群 24.83, SF5.0 群 18.53, ED5.0 群 $29.75 \mathrm{nmol} / \mathrm{g}$ tissue であ り, PCS 群に比べ SF2.5 群, SF5.0 群で Trp 濃度の 減少が認められ，ED5.0 群はほぼ同值であった. 5-HT 濃度は, SF2.5 群 2.20, SF5.0 群 2.08, ED5.0 群 2.44 $\mathrm{nmol} / \mathrm{g}$ tissue であり SF-1008C 投与群で減少傾向が 認められたが有意な差ではなかった。 5-HIAA 濃度は, SF2.5 群 2.02, SF5.0 群 1.85, ED5.0 群 $2.21 \mathrm{nmol} / \mathrm{g}$ tissue であり SF-1008C 投与群では PGS 群に比べ有
意に減少していた.

catecholamine (GA) 代謝系では, DA 濃度はSF2.5 群 6.68, SF5.0 群 7.09, ED5.0 群 $7.10 \mathrm{nmol} / \mathrm{g}$ tissue, また，NE 濃度は SF2.5 群 2.10, SF5.0 群 2.19, ED5.0 群 $2.19 \mathrm{nmol} / \mathrm{g}$ tissue であり各投与群と PCS 群の間 に差は認められなかった。

\section{3. 脳波に対する作用}

各群 1 例につき被験薬剤投与前及び投与後, $10 \%$ ammonium acetate 溶液 $3 \mathrm{ml} / \mathrm{kg}$ 腹腔内投与後の脳 波を図3に示した. また, 周波数帯域 $0.5 \sim 25.5 \mathrm{~Hz}$ のパワーを求め, $10 \%$ ammonium acetate 溶液投与 時のパワーを $100 \%$ とした場合の百分率の経時变化を図 4 に示した. 


\begin{tabular}{|c|c|c|c|c|}
\hline & $\begin{array}{l}\text { Sham } \\
\qquad \text { (woter } 10 \mathrm{~m} / \mathrm{kg})\end{array}$ & $\begin{array}{l}\text { PCS } \\
\text { (Woter } 10 \mathrm{~m} / / \mathrm{kg})\end{array}$ & $\begin{array}{l}\text { SF } 5.0 \\
\quad(S F-1008 \mathrm{C} \quad 5 \mathrm{~g} / \mathrm{kg})\end{array}$ & $\begin{array}{l}\text { ED } 5.0 \\
\text { (ED-AC } 5 g / \mathrm{kg})\end{array}$ \\
\hline Before & 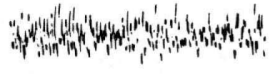 & y.t. & 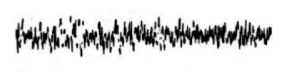 & 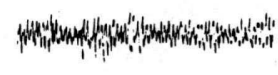 \\
\hline $0 \mathrm{~min}$ & 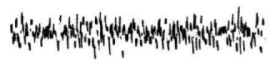 & 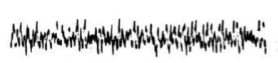 & 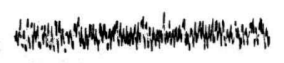 & How \\
\hline $10 \mathrm{~min}$ & ind & 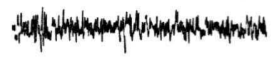 & 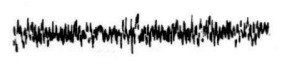 & mimmentrom \\
\hline $20 \mathrm{~min}$ & 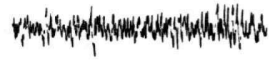 & 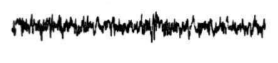 & 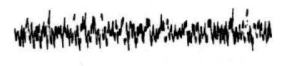 & 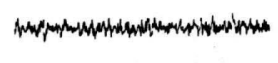 \\
\hline $30 \mathrm{~min}$ & 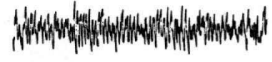 & 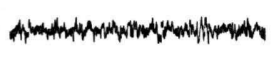 & 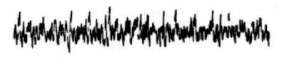 & (n) \\
\hline $40 \mathrm{~min}$ & 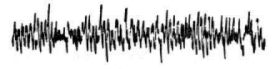 & 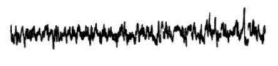 & 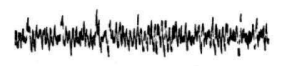 & 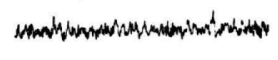 \\
\hline $50 \mathrm{~min}$ & 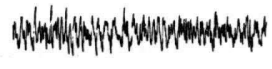 & 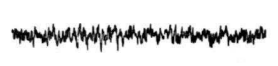 & 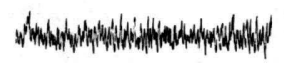 & 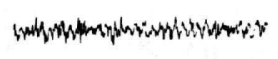 \\
\hline $60 \mathrm{~min}$ & 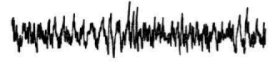 & 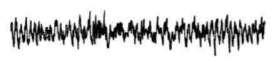 & 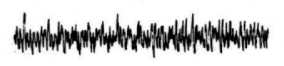 & 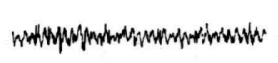 \\
\hline & $ل_{2}$ & $5 \mathrm{sec}$ & $ل_{200}$ & 5 sec \\
\hline
\end{tabular}

Fig. 3 Effect of SF-1008C on electroencephalogram after acute ammonia loading in portacaval shunted rats.

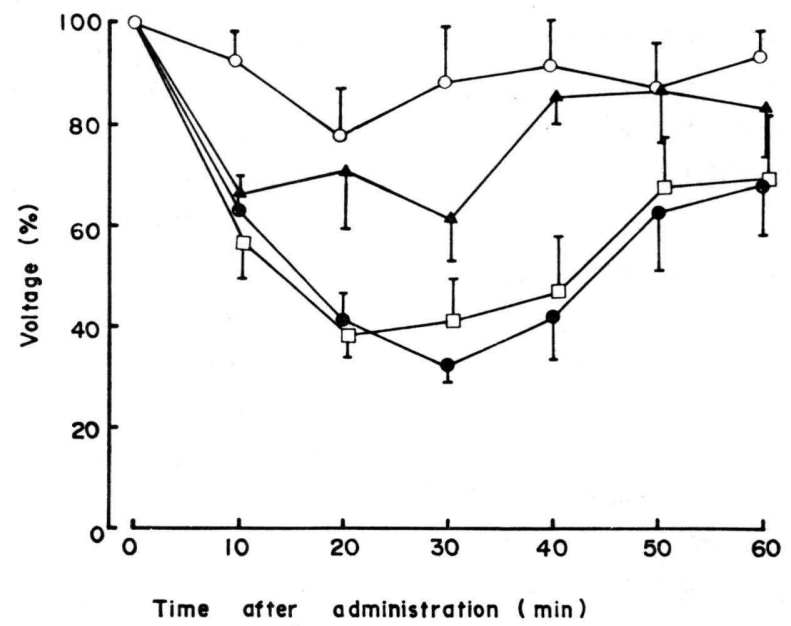

Fig. 4 Changes in electroencephalographic voltage after acute ammonia loading in portacaval shunted rats. The results are expressed as mean \pm standard deviation. $\bigcirc-\bigcirc$ : Sham, PCS, $\mathbf{\Delta}-\mathbf{\Delta}$ : SF5.0, $\square-\square$ : ED5.0. 
$10 \%$ ammonium acetate 溶液 $3 \mathrm{ml} / \mathrm{kg}$ 腹腔内投与 後, Sham 群においては, 脳波電位の低下は活とんど認 められなかったが，PCS 群においては，脳波電位の低 下が認められた. SF5.0 群沉执いて脳波電位の低下が抑 制されたが，ED5.0 群では脳波電位の低下はほとんど 抑制されなかった（図 3 ).

テレビモニターでの観察と脳波との関係では，Sham 群においては, 正向反射が存在し, PCS 群では, 脳波 電位の低下に相応して正向反射の消失が認められた。 SF5.0 群では, 正向反射の消失が 4 例中 1 例と少なく, 正向反射が消失した例においてもその回復が早かった. 一方, ED5.0 群では, 正向反射の消失は PCS 群と同 程度であった.

\section{考察}

肝性脳症は肝疾患によって，二次的におこる精神神経 症候群であり ${ }^{1)}$, 古くから知られている肝脳疾患の一つ である. 肝性脳症の初期症状には, flapping tremor などの錐体外路症状, そして, 見当識障害, 異常行動や 錯乱などの精神症状がある，最近，この肝性脳症の病 態, 治療の研究モデルとして PGS ラットが用いられて いる. PCS ラットの血漿中遊離 amino acid 濃度の変

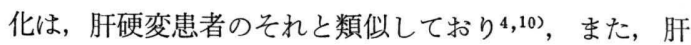
機能の変化 ${ }^{12)}$ が見られることが報告され，脳内 amine 代謝異常に関しても多くの報告がなされている13,14).

PCS ラットの精神神経症状などの病態生理学的な变 化についての報告では，PCS により自発運動に抢ける circadian rhythm の消失 ${ }^{15}$, 肝性脳症患者飞類似乙 た睡眠・覚醒リズムの異常 ${ }^{16)}$, 脑波覚醒反応閾值の低 下 ${ }^{17)}$, 学習行動の異常 ${ }^{18)}$, social behavior の異常19)の 報告がある，一方，外見上の変化はほとんど認められな (、20)との報告もある.

本試験では, 実験モデルとして ammonia 負荷 PCS ラットを用い, 血中 ammonia 濃度, 血漿中ょょび脳 内遊離 amino acid 濃度, 脳内 amine 濃度および脳 波を測定した。ささらに，肝不全用経腸栄養剤 SF-1008C の肝性脳症に対する効果についても検討を加光た. ammonium acetate の投与量は, PCS 群が正向反射 を失う最小值として設定し，昏睡状態がピークになる 投与30分後に解剖した. PCS ラットは, ammonia を 負荷しなくても正常ラットよりも高い血中 ammonia 濃度 $(200 \sim 300 \mu \mathrm{g} / \mathrm{dl})$ を示すが ${ }^{10)}$ ，昏睡を起こすこと はなく，外見上の変化も殆どみられない。この PCS ラ ットに対する SF-1008C の効果については既に報告し
た ${ }^{10)}$ ，本試験においても，SF-1008C を投与した場合の 血中 ammonia 濃度は，ED5.0 群付対して有意に低く 保たれ，PGS 群に比べても低值であった．これは蛋白 質成分中の BCAA を強化した SF-1008C によって, 血中 ammonia 濃度を増加させることなく, 窒素補給 が可能であることを示唆している.

肝性腷症惹起因子として古くより ammonia が注目 されており, その作用については, 脳内 ATP の減

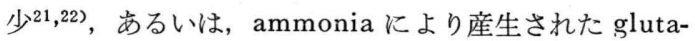
mine (Gln) と血漿中の中性 amino acid の交換によ り脳内中性 amino acid 濃度が増加し, これにより神 経伝達物質の代謝に变化が生じて脳症が誘発されると の仮説が提唱されている23). PCS 手術後 ammonium acetate を負荷した動物の血漿中遊離 amino acid 濃 度は, Sham 群に比較し AAA 濃度が有意に増加して いた. さらに, Sham 群に比較し BCAA, AAA 濃度 の双方が増加して打り, ammonium acetate を負荷す ることより脳内中性 amino acid 濃度が増加すると考 えられた。血漿中および脳内遊離 amino acid 濃度に 対する SF-1008C の効果は, PCS ラットでの効果 ${ }^{10)}$ 同様に, 血漿中遊離 amino acid 濃度異常を是正し, さらに脳内遊離 amino acid 濃度異常を是正すること と考光られた。

図 2 亿, 血漿中 BCAA/AAA 比々脳内 BCAA/AAA 比の相関を示した．血漿中 BCAA/AAA 比と脳内 BGAA/AAA 比との間には, 正の相関関係 $(r=0.9585)$ が認められ, 血漿中遊離 amino acid 濃度が脳内遊離 amino acid 濃度を反映していることが示唆された.

肝性脳症 と血漿中遊離 amino acid 濃度異常, 脳内 amine 代謝異常との関係について, 1971年, Fischer and Baldessarini ${ }^{24)}$ は, Tyr, Phe と由来する amine 類のうち octopamine, $\beta$-phenylethanolamine $か$ 脳内 で増加して, 偽性神経伝達物質として作用し昏睡を誘発 させると主張した。 また，1975年，Munro ら 25! は，脳 内 $\operatorname{Trp}$ の蓄積により 5-HT が増加し昏睡を誘発させ ると主張した.

ammonia 負荷 PGS ラットの脳内 amine 濃度は,

Trp, 5-HIAA 濃度が有意に増加し, DA 濃度が有意に 減少した. SF-1008C は, 増加した Trp, 5-HIAA 濃 度を減少させ, 脳内 5-HT 代謝に影響を及ぼした。一 方，ED-AC は，Trp，5-HIAA 濃度に影響を及ぼさな かった.このことは，SF-1008C が血漿中遊離 amino acid 濃度異常を是正し, さらに, 脳内遊離 amino acid 濃度異常を是正することにより脳内 amine 代謝にまで 
影響を及ぼしていることを示唆するものであり，臨床に お忛る SF-1008C の血漿中 amino acid 濃度異常の是

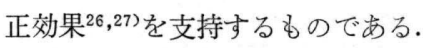

ammonium acetate 腹腔内投与直後の脳波電位のパ ワーを100\%とした場合, PCS 群で脳波電位が経時的に 低下し30分で32\%に低下した. この時ラットは, 正向反 射が消失して抢り, 脳波電位の回復上之もに正向反射も 回復した。つまり, 脳波電位の低下と正向反射の消失と が相応していることが観察された．SF-1008C 投与によ ってモデル動物の ammonium acetate による脳波電 位パワー低下が抑制されたが，血中 ammonia 濃度の 低下が軽度であったことから, SF-1008C は ammonia の血中即ち脳内濃度を低下させるといらことだけで説明 できない. SF-1008C は, 脳内 amino acid 濃度の正 常化によって ammonia の脳波パワー低下作用に拮抗 するものであろう.

PCS ラットに ammonia を負荷することにより脳波 の徐波, 脳波電位の低下ならびに行動異常の出現が報告 されている28,29).さらに, 臨床的にも, 肝性昏睡時に脳 波の低電位化がおこり, 症状の回復とともに脳波の電 位回復が報告されていることから ${ }^{30)}$, ammonia 負荷 PCS ラットの脳波電位は, 肝性脳症の一つの指標と考 えた.

これらの成績は, SF-1008C が，血漿中遊離 amino acid 濃度異常を是正することにより脳内遊離 amino acid 濃度ひいては脳内 amine 濃度および脳波に影響 を及ぼしていることを示唆するものである.

\section{文献}

1) Schenker, S., Breen, K.J. and Hoyumpa, A.M.: Gastroenterology 66, 121 (1974)

2) Fischer, J.E., Funovics, J.M., Aguirre, A., James, J.H., Keane, J.M., Wesdorp, R.I.C., Yoshimura, N. and Westman, T.: Surgery 78, 276 (1975)

3) Fischer, J.E., Rosen, H.M., Ebeid, A.M., James, J.H., Keane, J.M. and Soeters, P.B.: Surgery 80, 77 (1976)

4) 川出靖彦, 小畠正夫, 橋本 修, 松井園生 : 現代の 診療 20, 1191 (1978)

5) 塩田哲也, 渡辺明治, 沖田美佐子, 長島秀夫 : 薬理 と治療 11, 1193 (1983)

6) Okita, M., Watanabe, A., Shiota, T., Sakata, T. and Nagashima, H.: Curr. Ther. Res. 35,
1049 (1984)

7) 奥村 恂: 治療 63, 1433 (1981)

8) 佐藤 博, 川村 功, 小越章平: 日本臨床 37 , 3031 (1979)

9) 小畠正夫, 中村俊之, 坂田義一, 冨田栄一, 橋本 修, 川出靖彦: 医学のあゆみ 110,45（1979）

10) 木戸康博, 杉山光太, 樫山英二, 中尾誠仁, 工藤庄 次, 須田武雄, 宮本剛八郎, 清水剛文, 郡 英明 : 薬理と治療 13，4103（1985）

11 ) 奥田拓道, 藤井節郎 : 最新医学 21, 622 (1966)

12) Lauterburg, B.H., Sautter, V., Preisig, R. and Bircher, J.: Gastroenterology 71, 221 (1976)

13) Cummings, M.G., James, J.H., Soeters, P.B., Keane, J.M., Foster, J. and Fischer, J.E.: J. Neurochem. 27, 741 (1976)

14) Bloxam, D.L. and Curzon, G.: J. Neurochem. 31, 1255 (1978)

15) Campbell, E., Ziparo, V., James, J.H. and Fischer, J.E.: Surg. Forum 30, 388 (1979)

16) 小林 勝, 松本淳治 : 四国医誌 38, 95 (1982)

17) Beaubernard, C., Salomon, F. and Bismuth, H.: Biomedicine 32, 76 (1980)

18）奥寺文彦: 日大医誌 39, 853 (1980)

19) Trichlebank, M.D., Smart, J.L., Bloxam, D.L. and Curzon, G.: Pharmacol. Biochem. Behav. 9, 181 (1978)

20) Bucci, L., Cardelli, M., Chiavarelli, R., Massotti, M. and Morisi, G.: Intern. J. Neurosci. 10, 129 (1980)

21) Schenker, S., McGandless, D.W., Brophy, E. and Lewis, M.S.: J. Clin. Invest. 46, 838 (1967)

22) McGandless, D.W. and Schenker, S.: Exp. Brain Res. 44, 325 (1981)

23) James, J.H., Ziparo, V., Jeppsson, B. and Fischer, J.E.: Lancet ii, 772 (1979)

24) Fischer, J.E. and Baldessarini, R.J.: Lancet ii, 75 (1971)

25) Munro, H.N., Fernstrom, J.D. and Wurtman, R.J.: Lancet i, 722 (1975)

26 ) 鈴木一幸, 加藤章信, 滝川康裕, 井上義博, 黒沢 照男, 村上昌彦, 柏原紀文, 紫桃正裕, 佐藤俊一： J. J. P. E. N. 16, 339 (1984)

27) Okita, M., Watanabe, A. and Nagashima, H.: J. Nutr. Sci. Vitaminol. 31, 291 (1985)

28) Weitzman, E.D., Rapport, M.M., McGregor, P. and Jacoby, J.: Science 160, 1361 (1968)

29) Lin, S. and Raabe, W.: J. Neurochem. 44, 1252 (1985)

30) Tanaka, S., Yano, Y., Sakamoto, H. and Ohbayashi, A.: Lancet 1379 (1980) 
Abstract - Study of the ameliorating effects of an enteral nutrient for liver failure on hepatic encephalopathy: Effects of SF-1008C on plasma and brain free amino acids, intracerebral amine concentrations and electroencephalogram in portacaval shunted rats with ammonia loading. Yasuhiro KIDO, Kohta SUGIYAMA, Seiji NAKAO, Eiji KASHIYAMA, Takeo SUDA, Gohachiro MIYAMOTO, Takefumi SHIMIZU, Shigeyuki SHINTANI and Hideaki KOHRI (Tokushima Research Institute, Otsuka Pharmaceutical Co., Ltd., 463-10 Kagasuno, Kawauchi-cho, Tokushima 771-01). Folia pharmacol. japon. 88, 47 56 (1986)

The ameliorating effects of an enteral nutrient for liver failure (SF-1008C), which is enriched with branched-chain amino acids (BCAA) and includes few aromatic amino acids (AAA), were investigated. The blood ammonia, plasma and brain free amino acids, intracerebral amine concentrations and electroencephalogram were measured in portacaval shunted rats with $10 \%$ ammonium acetate (3 ml/kg, i.p.) (PCS) as a model of hepatic encephalopathy. The blood ammonia and plasma free amino acid concentrations in PCS rats were significantly increased in comparison to sham-operated (Sham) rats. Thus, the plasma BCAA/AAA ratio in PCS rats was appreciably reduced. Concomitant with the abnormal plasma amino acid concentrations, the brain free amino acid concentrations in PCS rats were markedly increased in comparison to the Sham rats. Moreover, the intracerebral tryptophan (Trp) and 5-hydroxyindol acetic acid (5-HIAA) concentrations were significantly increased, and the intracerebral dopamine (DA) concentration was significantly decreased in the PCS rats. The intracerebral serotonin (5-HT) and norepinephrine (NE) concentrations were, however, hardly changed. A smaller voltage for the electroencephalogram was used in the PCS rats than in the Sham rats. Abnormal plasma and brain free amino acid concentrations in PCS rats were normalized by oral administration of SF-1008C, and the low voltage electroencephalograms in the PCS rats were suppressed. On the other hand, abnormal plasma and brain free amino acid concentrations in the PCS rats were hardly normalized by oral administration of ED-AC, an elemental diet based on an amino acid composition of egg protein. These results suggest that SF-1008C affects brain free amino acids, intracerebral amine concentrations and electroencephalogram by ameliorating abnormal plasma free amino acid concentrations. Moreover, there is a highly significant correlation between the plasma BCAA/AAA ratio and the brain BCAA/AAA ratio, and this finding suggests that the plasma free amino acid patterns reflect the brain free amino acid patterns. 